Article

\title{
Bioactive Diphenyl Ethers and Isocoumarin Derivatives from a Gorgonian-Derived Fungus Phoma sp. (TA07-1)
}

\author{
Ting Shi ${ }^{1,2}$, Jun Qi ${ }^{1,2}$, Chang-Lun Shao ${ }^{1,2}$, Dong-Lin Zhao ${ }^{1,2}$, Xue-Mei Hou ${ }^{1,2}$ and \\ Chang-Yun Wang ${ }^{1,2,3, *}$ \\ 1 Key Laboratory of Marine Drugs, School of Medicine and Pharmacy, Ocean University of China, \\ the Ministry of Education of China, Qingdao 266003, China; shiting_jia@126.com (T.S.); \\ qljbgreat@163.com (J.Q.); shaochanglun@163.com (C.-L.S.); zhaodonglin@caas.cn (D.-L.Z.); \\ houxuemei_1990@163.com (X.-M.H.) \\ 2 Laboratory for Marine Drugs and Bioproducts, Qingdao National Laboratory for Marine Science \\ and Technology, Qingdao 266071, China \\ 3 Institute of Evolution \& Marine Biodiversity, Ocean University of China, Qingdao 266003, China \\ * Correspondence: changyun@ouc.edu.cn; Tel./Fax: +86-532-8203-1536
}

Academic Editor: Peer B. Jacobson

Received: 25 March 2017; Accepted: 23 May 2017; Published: 25 May 2017

\begin{abstract}
Three new diphenyl ether derivatives-phomaethers A-C (1-3) and five known compounds-including a diphenyl ether analog, 2,3'-dihydroxy-4-methoxy-5',6-dimethyl diphenyl ether (4); and four isocoumarin derivatives, diaportinol (5), desmethyldiaportinol (6), citreoisocoumarinol (7), and citreoisocoumarin (8) -were isolated from a gorgonian-derived fungus Phoma sp. (TA07-1). Their structures were elucidated by extensive spectroscopic investigation. The absolute configurations of $\mathbf{1}$ and $\mathbf{2}$ were determined by acid hydrolysis reactions. It was the first report to discover the diphenyl glycoside derivatives from coral-derived fungi. Compounds 1,3 , and 4 showed selective strong antibacterial activity against five pathogenic bacteria with the minimum inhibiting concentration (MIC) values and minimum bactericidal concentration (MBC) values between 0.156 and $10.0 \mu \mathrm{M}$.
\end{abstract}

Keywords: gorgonian-derived fungus; Phoma sp.; diphenyl ether; isocoumarin; antibacterial activity

\section{Introduction}

Marine microorganisms, especially marine fungi, have got more and more attention in recent years, as their outstanding abilities to produce bioactive compounds [1-3]. Among marine fungi, coral-derived fungi have played an important role in discovering pharmaceutical useful compounds [4]. Marine-derived Phoma sp. has been found to produce many novel and bioactive secondary metabolites such as cytotoxic epoxyphomalin A [5] and phomazine B [6], antifouling (+)-flavipucine [7], and antibacterial phomalevones A-C [8]. During our ongoing investigation for new bioactive compounds from gorgonian-derived fungi in the South China Sea [9-13], the fungal strain Phoma sp. (TA07-1) isolated from gorgonian Dichotella gemmacea attracted our attention, because its EtOAc extract of the fermentation showed significant antibacterial activity towards two Gram-positive bacteria, Staphylococcus albus and S. aureus, and three Gram-negative bacteria Escherichia coli, Vibrio parahaemolyticus, and V. anguillarum. Bioassay-guided separation led to the isolation of four diphenyl ether derivatives, including three new compounds, phomaethers A-C (1-3), and 2,3'-dihydroxy-4-methoxy-5',6-dimethyl diphenyl ether (4) [14], together with four known isocoumarin derivatives, diaportinol (5) [15], desmethyldiaportinol (6) [16], citreoisocoumarinol (7) [17], 
and citreoisocoumarin (8) [17] (Figure 1). Herein we report the isolation, structure elucidation, and bioactivities of these compounds.

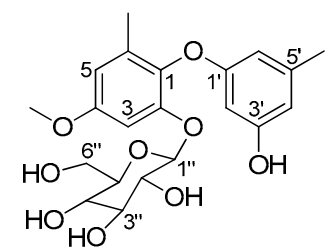

1<smiles>COc1cc(O)c2c(=O)oc(C[C@H](O)CO)cc2c1</smiles>

5<smiles>COc1cc(O)c(Oc2cc(C)cc(Oc3c(C)cc(OC)c(O)c3CO)c2)c(O)c1</smiles><smiles>O=c1oc(C[C@H](O)CO)cc2cc(O)cc(O)c12</smiles><smiles>COc1cc(O)c(Oc2cc(C)cc(O)c2)c(C)c1OC</smiles>

3<smiles>C[C@H](O)C[C@H](O)Cc1cc2cc(O)cc(O)c2c(=O)o1</smiles><smiles>COc1cc(C)c(Oc2cc(C)cc(O)c2)c(O)c1</smiles>

4

Figure 1. Structures of compounds 1-8.

\section{Results and Discussion}

Phomaether A (1) was isolated as a colorless, amorphous powder. The molecular formula of $\mathrm{C}_{21} \mathrm{H}_{26} \mathrm{O}_{9}$ was determined by HRESIMS that displayed the $[\mathrm{M}+\mathrm{Na}]^{+}$peak at $\mathrm{m} / z 445.1474$ (calcd. for $\mathrm{C}_{21} \mathrm{H}_{26} \mathrm{O}_{9} \mathrm{Na}$, 445.1469) indicating nine degrees of unsaturation. The ${ }^{1} \mathrm{H}$ NMR spectrum (Table 1) displayed five aromatic proton signals at $\delta_{\mathrm{H}} 6.69(1 \mathrm{H}, \mathrm{d}, J=2.9 \mathrm{~Hz}), 6.51(1 \mathrm{H}, \mathrm{d}, J=2.9 \mathrm{~Hz}), 6.18$ $(1 \mathrm{H}, \mathrm{brs}), 6.08(1 \mathrm{H}, \mathrm{brs})$ and $5.93(1 \mathrm{H}, \mathrm{brs})$, two methyls at $\delta_{\mathrm{H}} 2.13(3 \mathrm{H}, \mathrm{s})$ and $2.02(3 \mathrm{H}, \mathrm{s})$, one methoxyl at $\delta_{\mathrm{H}} 3.73(3 \mathrm{H}, \mathrm{s})$, and a hydroxyl at $\delta_{\mathrm{H}} 9.27\left(1 \mathrm{H}\right.$, brs). The ${ }^{13} \mathrm{C}$ NMR (Table 1$)$ showed 12 aromatic carbon signals at $\delta_{C} 159.3,158.2,156.3,150.9,139.5,135.2,132.4,109.4,108.5,106.6,100.82$, and 99.2; two methyls at $\delta_{C} 21.2,16.2$; and a methoxyl at $\delta_{C} 55.2$. The NMR spectral feature indicated that 1 was a diphenyl ether derivative and very similar to $2,3^{\prime}$-dihydroxy-4-methoxy-5',6-dimethyl diphenyl ether (4) [14]. The difference between these two compounds was the presence of a hexose residue in 1 . The signals of the hexose residue in ${ }^{1} \mathrm{H}$ NMR and ${ }^{13} \mathrm{C}$ NMR displayed five oxymethines $\left(\delta_{\mathrm{H}} 4.82, \delta_{\mathrm{C}} 100.76 ; \delta_{\mathrm{H}} 3.30, \delta_{\mathrm{C}} 77.3 ; \delta_{\mathrm{H}} 3.20, \delta_{\mathrm{C}} 76.8 ; \delta_{\mathrm{H}} 3.06, \delta_{\mathrm{C}} 73.2 ; \delta_{\mathrm{H}} 3.08, \delta_{\mathrm{C}} 69.8\right)$, one oxymethylene $\left(\delta_{\mathrm{H}} 3.68,3.40, \delta_{\mathrm{C}} 60.8\right)$, and four hydroxyls $\left(\delta_{\mathrm{H}} 5.04,5.04,4.68,4.60\right)$, and the hexose was determined as glucopyranose comparing to the NMR data with those of flavonoid glycoside, $4^{\prime}$-demethylleucomin-7-O- $\beta$-D-glucopyranoside [18]. The correlation from $\mathrm{H}-1^{\prime \prime}$ to $\mathrm{C}-2$ in $\mathrm{HMBC}$ (Figure 2) indicated the glucosyl was linked to C-2. The relative configuration of glucopyranose in 1 was determined by the ${ }^{1} \mathrm{H}_{-}{ }^{1} \mathrm{H}$ coupling constants. The large coupling constant between $\mathrm{H}-1^{\prime \prime}$ and $\mathrm{H}-2^{\prime \prime}(J=7.8 \mathrm{~Hz})$ indicated a $\beta$-configuration of the glucopyranose [19]. The configuration of the glucopyranose was determined as D-glucopyranose by comparing the rotation of its acid hydrolysate $\left([\alpha]_{\mathrm{D}}^{25}+48.0\left(c 0.04, \mathrm{H}_{2} \mathrm{O}\right)\right)$ with that of the standard D-glucopyranose $\left([\alpha]_{\mathrm{D}}^{25}+54.0(c 0.15\right.$, $\left.\mathrm{H}_{2} \mathrm{O}\right)$ ). Accordingly, 1 was determined as 2-O- $\beta$-D-glucopyranose- $3^{\prime}$-hydroxy-4-methoxy-5',6-dimethyl diphenyl ether, and was named phomaether A.

Phomaether B (2) was isolated as a light brown, amorphous powder. The molecular formula was assigned as $\mathrm{C}_{20} \mathrm{H}_{24} \mathrm{O}_{8}$ (nine degrees of unsaturation) by its HRESIMS data. Detailed inspection of the NMR data (Table 1) of $\mathbf{2}$ with those of $\mathbf{1}$ revealed that these two compounds were very similar, except for the sugar moiety. The sugar residue in 2 was defined as a ribose by comparing the NMR data (Table 1) with those of naphthyl ribofuranoside, isotorachrysone-6-O- $\alpha$-D-ribofuranoside [20], chromene glycoside, and sterin A [21]. The key HMBC correlation from $\mathrm{H}-1^{\prime \prime}$ to C-3' (Figure 2) established the connection between the ribose and diphenyl ether moiety. The coupling constant of anomeric proton $\mathrm{H}-1^{\prime \prime}(J=4.5 \mathrm{~Hz})$ in 2 was found to close to that in methyl- $\alpha$-D-ribofuranoside $(J=4.3 \mathrm{~Hz})$ [22], indicating an $\alpha$-ribose in 2 . The $\alpha$-ribose was determined as D-configuration by comparing the optical rotation data of the acid hydrolysate of 2 with that of the standard 
D-ribose $\left([\alpha]_{\mathrm{D}}^{25}-23.0(c) 0.03, \mathrm{H}_{2} \mathrm{O}\right)$ vs. $\left.\left.[\alpha]_{\mathrm{D}}^{25}-38.7(c) 0.10, \mathrm{H}_{2} \mathrm{O}\right)\right)$. From above, 2 was determined as 2-hydroxy-3'-O- $\alpha$-D-ribofuranoside-4-methoxy-5',6-dimethyl diphenyl ether, and named phomaether $B$.

Table 1. NMR spectroscopic data (600/150 MHz) for compounds 1-3.

\begin{tabular}{|c|c|c|c|c|c|c|}
\hline Position & $1, \delta_{C}$ Type & $1, \delta_{H}$ Mult. $(J$ in $\mathrm{Hz})$ & $2, \delta_{C}$ Type & $\begin{array}{c}2, \delta_{\mathrm{H}} \text { Mult. } \\
(J \text { in } \mathrm{Hz})\end{array}$ & $3, \delta_{C}$ Type & $\begin{array}{c}\text { 3, } \delta_{H} \text { Mult. } \\
(J \text { in Hz) }\end{array}$ \\
\hline 1 & $135.2 \mathrm{C}$ & & $135.6 \mathrm{C}$ & & $134.7 \mathrm{C}$ & \\
\hline 2 & $150.9 \mathrm{C}$ & & $151.8 \mathrm{C}$ & & $147.5 \mathrm{C}$ & \\
\hline 3 & $100.82 \mathrm{CH}$ & $6.69, \mathrm{~d}(2.9)$ & $101.4 \mathrm{CH}$ & $6.35, \mathrm{~d}(2.9)$ & $100.0 \mathrm{CH}$ & $6.49, \mathrm{~s}$ \\
\hline 4 & $156.3 \mathrm{C}$ & & $158.7 \mathrm{C}$ & & $151.7 \mathrm{C}$ & \\
\hline 5 & $108.5 \mathrm{CH}$ & $6.51, \mathrm{~d}(2.8)$ & $107.8 \mathrm{CH}$ & $6.31, \mathrm{~d}(2.9)$ & $141.3 \mathrm{C}$ & \\
\hline 6 & $132.4 \mathrm{C}$ & & $134.0 \mathrm{C}$ & & $127.2 \mathrm{C}$ & \\
\hline $1^{\prime}$ & $159.3 \mathrm{C}$ & & $160.7 \mathrm{C}$ & & $160.8 \mathrm{C}$ & \\
\hline $2^{\prime}$ & $99.2 \mathrm{CH}$ & 5.93, brs & $102.6 \mathrm{CH}$ & 6.39, brs & $100.3 \mathrm{CH}$ & 6.02, brs \\
\hline $3^{\prime}$ & $158.2 \mathrm{C}$ & & $159.8 \mathrm{C}$ & & $159.4 \mathrm{C}$ & \\
\hline $4^{\prime}$ & $109.4 \mathrm{CH}$ & 6.18, brs & $111.7 \mathrm{CH}$ & 6.60, brs & $110.4 \mathrm{CH}$ & 6.24 , brs \\
\hline $5^{\prime}$ & $139.5 \mathrm{C}$ & & $141.3 \mathrm{C}$ & & $141.4 \mathrm{C}$ & \\
\hline $6^{\prime}$ & $106.6 \mathrm{CH}$ & 6.08, brs & $110.4 \mathrm{CH}$ & 6.29 , brs & $108.1 \mathrm{CH}$ & 6.15 , brs \\
\hline $1^{\prime \prime}$ & $100.76 \mathrm{CH}$ & $4.82, \mathrm{~d}(7.8)$ & $102.3 \mathrm{CH}$ & $5.55, \mathrm{~d}(4.5)$ & & \\
\hline $2^{\prime \prime}$ & $73.2 \mathrm{CH}$ & $3.06, \mathrm{~m}$ & $73.4 \mathrm{CH}$ & $4.13, \mathrm{dd}(6.4,4.5)$ & & \\
\hline $3^{\prime \prime}$ & $76.8 \mathrm{CH}$ & $3.20, \mathrm{dd}(8.9,8.8)$ & $71.2 \mathrm{CH}$ & 4.06, dd $(6.5,3.2)$ & & \\
\hline $4^{\prime \prime}$ & $69.8 \mathrm{CH}$ & $3.08, \mathrm{~m}$ & $87.5 \mathrm{CH}$ & $4.10, \mathrm{dt}(3.5,3.5)$ & & \\
\hline \multirow[t]{2}{*}{$5^{\prime \prime}$} & $77.3 \mathrm{CH}$ & 3.30 , ddd $(8.4,6.4,2.0)$ & $63.2 \mathrm{CH}_{2}$ & 3.69 , dd $(12.1,3.4)$ & & \\
\hline & & & & 3.63 , dd $(12.2,3.8)$ & & \\
\hline \multirow[t]{2}{*}{$6^{\prime \prime}$} & $60.8 \mathrm{CH}_{2}$ & $3.68, \mathrm{~d}(11.0)$ & & & & \\
\hline & & $3.40, \mathrm{~d}(11.0)$ & & & & \\
\hline 4-OMe & $55.2 \mathrm{OCH}_{3}$ & $3.73, \mathrm{~s}$ & $55.8 \mathrm{OCH}_{3}$ & $3.74, \mathrm{~s}$ & $56.4 \mathrm{OCH}_{3}$ & $3.81, \mathrm{~s}$ \\
\hline 5-OMe & & & & & $61.0 \mathrm{OCH}_{3}$ & $3.70, \mathrm{~s}$ \\
\hline 6-Me & $16.2 \mathrm{CH}_{3}$ & $2.02, \mathrm{~s}$ & $16.5 \mathrm{CH}_{3}$ & $2.03, \mathrm{~s}$ & $9.8 \mathrm{CH}_{3}$ & $1.98, \mathrm{~s}$ \\
\hline $3^{\prime}-\mathrm{OH}$ & & 9.27 , brs & & & & \\
\hline $5^{\prime}-\mathrm{Me}$ & $21.2 \mathrm{CH}_{3}$ & $2.13, \mathrm{~s}$ & $21.8 \mathrm{CH}_{3}$ & $2.24, \mathrm{~s}$ & $21.6 \mathrm{CH}_{3}$ & $2.18, \mathrm{~s}$ \\
\hline $2^{\prime \prime}-\mathrm{OH}$ & & 5.04 , brs & & & & \\
\hline $3^{\prime \prime}-\mathrm{OH}$ & & 5.04 , brs & & & & \\
\hline $4^{\prime \prime}-\mathrm{OH}$ & & $4.68, \mathrm{~d}(5.2)$ & & & & \\
\hline $6^{\prime \prime}-\mathrm{OH}$ & & 4.60 , brs & & & & \\
\hline
\end{tabular}

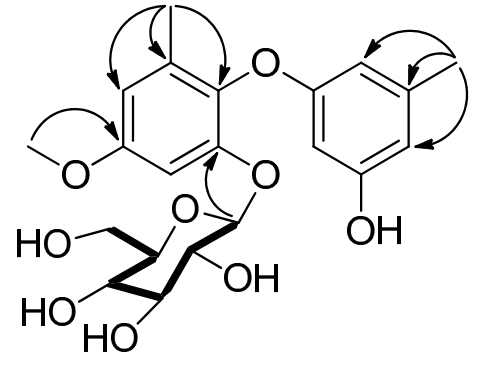

1

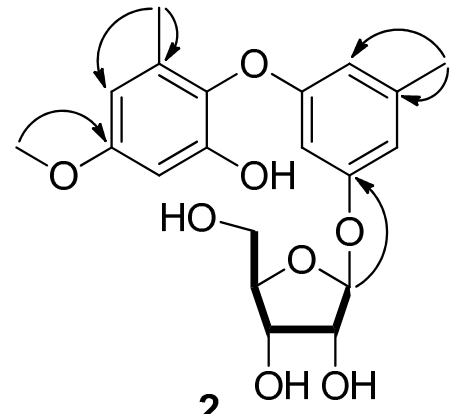

2

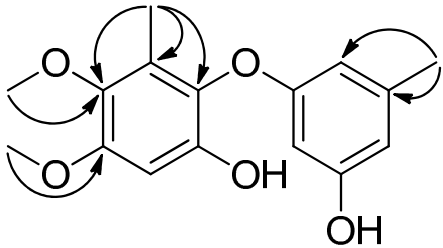

3

Figure 2. ${ }^{1} \mathrm{H}-{ }^{1} \mathrm{H}$ COSY $(\longrightarrow)$ and $\mathrm{HMBC}(\smile)$ correlations for compounds $1-3$.

A literature survey revealed that the diphenyl glycoside derivatives were rare in marine natural products. To the best of our knowledge, a diphenyl glycoside was found from a sponge-derived fungus Metarhizium anisopliae [23]. In present study, the diphenyl glycoside derivatives were reported for the first time isolated from coral-derived fungi.

Phomaether $\mathrm{C}(3)$ was obtained as a colorless powder with a molecular formula $\mathrm{C}_{16} \mathrm{H}_{18} \mathrm{O}_{5}$, requiring eight degrees of unsaturation. The NMR data (Table 1) indicated that 3 is very similar to 2,3'-dihydroxy-4-methoxy-5',6-dimethyl diphenyl ether (4) [14]. The only difference was the presence of an additional methoxyl in 3. The correlation from 5-OMe to C-5 in HMBC (Figure 2) indicated that the additional methoxyl was anchored at C-5. Thus, 3 was determined as 2,3'-dihydroxy-4,5-dimethoxy-5',6-dimethyl diphenyl ether, and named phomaether C. 
The structures of 4, 5, 6, 7, and 8 were determined as 2,3'-dihydroxy-4-methoxy-5',6-dimethyl diphenyl ether [14], diaportinol [15], desmethyldiaportinol [16], citreoisocoumarinol [17], citreoisocoumarin [17], respectively, by comparing their NMR data with those in the literature.

All the isolated compounds (1-8) were evaluated for their antibacterial activity against a panel of pathogenic bacteria, including two Gram-positive bacteria, S. albus and S. aureus, and three Gram-negative bacteria E. coli, V. parahaemolyticus, and V. anguillarum (Table 2). Compound 1 exhibited remarkable antibacterial activity against S. albus, S. aureus, E. coli, and V. parahaemolyticus with MIC values ranging from 0.312 to $0.625 \mu \mathrm{M}$ and MBC values from 0.625 to $2.50 \mu \mathrm{M}$. Compound 3 showed strong antibacterial activity to $S$. albus, S. aureus, and E. coli with MIC values ranging from 0.312 to $1.25 \mu \mathrm{M}$ and $\mathrm{MBC}$ values from 0.625 to $5.00 \mu \mathrm{M}$. It was notable that compound 4 showed strong antibacterial activity to all of the tested pathogenic bacteria, with MIC and MBC values ranging from 0.156 to $5.00 \mu \mathrm{M}$.

Table 2. Antibacterial activity of compounds 1, 3, and 4 .

\begin{tabular}{|c|c|c|c|c|c|c|}
\hline Compounds & \multicolumn{5}{|c|}{ MIC/MBC ( $\mu \mathrm{M})$} & Test Ranges \\
\hline 1 & $0.312 / 0.625$ & $0.625 / 0.625$ & $0.625 / 1.25$ & $0.625 / 2.50$ & $-1-$ & $0.039-20.0$ \\
\hline 4 & $0.312 / 0.312$ & $0.156 / 0.312$ & $0.156 / 0.156$ & $0.312 / 0.312$ & $2.50 / 5.00$ & $0.039-20.0$ \\
\hline Ciprofloxacin & $0.312 / 0.312$ & $0.156 / 0.156$ & $0.156 / 0.156$ & $0.156 / 0.156$ & $0.156 / 0.156$ & $0.010-10.0$ \\
\hline
\end{tabular}

Compounds 1-8 were also tested for their lethality to the brine shrimp, Artemia salina. Compounds 1, 3, and 4 showed moderate lethality to the brine shrimp A. salina with the $\mathrm{LC}_{50}$ values ranging from $14.01 \pm 0.36$ to $37.33 \pm 0.26 \mu \mathrm{g} / \mathrm{mL}$.

\section{Experimental Section}

\subsection{General Experimental Procedures}

Optical rotations were measured on a JASCO P-1020 digital polarimeter (JASCO Corporation, Tokyo, Japan). UV spectra were recorded using a Milton Roy spectrophotometer (Milton Roy, New York, NY, USA). IR spectra were recorded on a Nicolet-Nexus-470 spectrophotometer using KBr pellets (Thermo Electron, Waltham, MA, USA). NMR spectra were recorded on a JEOL Eclips-600 spectrometer (JEOL, Tokyo, Japan) at $600 \mathrm{MHz}$ for ${ }^{1} \mathrm{H}$ and $150 \mathrm{MHz}$ for ${ }^{13} \mathrm{C}$ in $\mathrm{CD}_{3} \mathrm{OD}$ or DMSO- $d_{6}$. Chemical shifts $\delta$ were recorded in ppm, using TMS as internal standard. ESIMS and HRESIMS spectra were measured on a Micromass Q-TOF spectrophotometer (Waters Corp., Manchester, UK) and a Thermo Scientific LTQ Orbitrap XL spectrometer (Thermo Fisher Scientific, Bremen, Germany), respectively. HPLC separation was performed using a Hitachi LA-2000 prep-HPLC system (Hitachi High Technologies, Tokyo, Japan) coupled with a Hitachi L-2455 photodiodearray detector (Hitachi High Technologies, Tokyo, Japan). A Kromasil $C_{18}$ semi-preparative HPLC column $(250 \times 10 \mathrm{~mm}, 5 \mu \mathrm{m})$ (Eka Nobel, Bohus, Sweden) was used. Silica gel (200-300 mesh; Qingdao Marine Chemical Group Co., Qingdao, China) and Sephadex LH-20 (Amersham Biosciences Inc., Piscataway, NJ, USA) were used for column chromatography. Precoated silica gel GF254 plates (Yantai Zifu Chemical Group Co., Yantai, China) were used for thin layer chromatography (TLC).

\subsection{Fungal Materials}

The fungus Phoma sp. (TA07-1) was isolated from a piece of fresh tissue from the inner part of the gorgonian Dichotella gemmacea (GX-WZ-2008003-4), collected from Weizhou coral reef in the South China Sea in September 2008. The strain was deposited in the Key Laboratory of Marine Drugs, the Ministry of Education of China, School of Medicine and Pharmacy, Ocean University of China, Qingdao, China, with the GenBank (NCBI) accession number KY556682. 


\subsection{Extraction and Isolation}

The fungal strain Phoma sp. (TA07-1) was fermented in a rice medium in 50 Erlenmeyer flasks $(500 \mathrm{~mL})$ at $28^{\circ} \mathrm{C}$ for four weeks. Each flask contained rice (Liaoyang City Jiapin Rice Co., LTD., Liaoyang, China) $80 \mathrm{~g}$, water $120 \mathrm{~mL}$ and sea salt (Qingdao Salt Industry Co., LTD., Qingdao, China) $2.0 \mathrm{~g}$. The cultivated solid medium was extracted repeatedly with EtOAc $(3 \times 300 \mathrm{~mL}$ for each flask). The combined EtOAc layer was evaporated to dryness under reduced pressure to afford a residue (10.0 g). The residue (10.0 g) was subjected to vacuum liquid chromatography (VLC) on silica gel using step gradient elution with EtOAc-petroleum ether (PE) (0-100\%) and then with $\mathrm{MeOH}-\mathrm{EtOAc}(0-100 \%)$ to afford nine fractions (Fr. 1-Fr. 9). Fr. 4 was first isolated by column chromatography (CC) on silica gel eluted with PE-EtOAc $(v / v, 8: 2)$, then subjected to Sephadex LH-20 $\mathrm{CC}$ with $\mathrm{PE}-\mathrm{CHCl}_{3}-\mathrm{MeOH}(v / v / v, 2: 1: 1)$, and further purified by using semi-preparative HPLC on an ODS column (Kromasil C18, $250 \times 10 \mathrm{~mm}, 5 \mu \mathrm{m}, 2 \mathrm{~mL} / \mathrm{min}$ ) eluted with $65 \% \mathrm{MeOH}-\mathrm{H}_{2} \mathrm{O}$ to give compound 4 (30.0 mg). Fr. 5 was separated on silica gel CC eluting with PE-EtOAc $(v / v, 7: 3)$, then isolated on Sephadex LH-20 CC with PE- $\mathrm{CHCl}_{3}-\mathrm{MeOH}(v / v / v, 2: 1: 1)$, and further purified on HPLC eluted with $60 \% \mathrm{MeOH}-\mathrm{H}_{2} \mathrm{O}$ to obtain compound $3(5.0 \mathrm{mg})$. Fr. 8 was eluted with $\mathrm{CHCl}_{3}-\mathrm{MeOH}(v / v$, 15:1) on silica gel CC, then eluted with $\mathrm{CHCl}_{3}-\mathrm{MeOH}(v / v, 1: 1)$ on Sephadex LH-20 CC, and further purified on HPLC with $40 \% \mathrm{MeOH}-\mathrm{H}_{2} \mathrm{O}$ for $6(6.0 \mathrm{mg}), 7(7.0 \mathrm{mg})$ and $8(5.0 \mathrm{mg}), 45 \% \mathrm{MeOH}-\mathrm{H}_{2} \mathrm{O}$ for $\mathbf{1}(5.0 \mathrm{mg})$ and $\mathbf{5}(6.0 \mathrm{mg})$, and $55 \% \mathrm{MeOH}-\mathrm{H}_{2} \mathrm{O}$ for $2(3.5 \mathrm{mg})$.

Phomaether A (1): colorless, amorphous powder; $[\alpha]_{\mathrm{D}}^{25}-2.1(c 0.40, \mathrm{MeOH}) ; \mathrm{UV}(\mathrm{MeOH}) \lambda_{\max }$ : 202 , 228, $278 \mathrm{~nm}$; IR (KBr) $v_{\max } 3470,2965,1565,1475,1320,1165,980 \mathrm{~cm}^{-1} ;{ }^{1} \mathrm{H}$ and ${ }^{13} \mathrm{C}$ NMR data, see Table 1; ESIMS $m / z 445.1[\mathrm{M}+\mathrm{Na}]^{+}, 867.2[2 \mathrm{M}+\mathrm{Na}]^{+}$; HRESIMS $m / z 445.1474[\mathrm{M}+\mathrm{Na}]^{+}$(calcd. for $^{2}$ $\left.\mathrm{C}_{21} \mathrm{H}_{26} \mathrm{O}_{9} \mathrm{Na}, 445.1469\right)$.

Phomaether B (2): light brown, amorphous powder; $[\alpha]_{\mathrm{D}}^{25}+8.0(c 0.20, \mathrm{MeOH})$; UV (MeOH) $\lambda_{\max }$ : 204 , 227, $278 \mathrm{~nm}$; IR (KBr) $v_{\max } 3312,2956,1566,1477,1332,1167,970 \mathrm{~cm}^{-1} ;{ }^{1} \mathrm{H}$ and ${ }^{13} \mathrm{C}$ NMR data, see Table 1; ESIMS $m / z$ 415.1 [M + Na $]^{+}, 807.1[2 \mathrm{M}+\mathrm{Na}]^{+}$; HRESIMS $m / z 415.1370[\mathrm{M}+\mathrm{Na}]^{+}$(calcd. for $\left.\mathrm{C}_{20} \mathrm{H}_{24} \mathrm{O}_{8} \mathrm{Na}, 415.1363\right)$.

Phomaether C (3): colorless powder; UV (MeOH) $\lambda_{\max }$ : 207, 226, $281 \mathrm{~nm}$; IR (KBr) $v_{\max } 3422,3310$, 2944, 1578, 1465, 1298, 1165, $975 \mathrm{~cm}^{-1} ;{ }^{1} \mathrm{H}$ and ${ }^{13} \mathrm{C}$ NMR data, see Table 1; ESIMS $m / z 290.9[\mathrm{M}+\mathrm{H}]^{+}$, $603.0[2 \mathrm{M}+\mathrm{Na}]^{+}$; HRESIMS $m / z 291.1168[\mathrm{M}+\mathrm{H}]^{+}$(calcd. for $\mathrm{C}_{16} \mathrm{H}_{19} \mathrm{O}_{5}, 291.1227$ ).

\subsection{Methanolysis of Compound $\mathbf{1}$}

Compound $1(2.0 \mathrm{mg})$ was dissolved in $5 \% \mathrm{HCl}-\mathrm{MeOH}(5 \mathrm{~mL})$ and refluxed at boiled temperature for $2 \mathrm{~h}$. The reaction mixture was neutralized and evaporated to give the residue. Then, the residue was extracted by $50 \%$ EtOAc- $\mathrm{H}_{2} \mathrm{O}$ to obtain aglycone. The configuration of D-glucoside was determined by comparing its rotation with that of the authentic sample.

\subsection{Methanolysis of Compound 2}

The aglycone of compound 2 was obtained by the same method for that of compound 1. The configuration of D-ribose was determined by comparing its rotation with that of a standard sample.

\subsection{Biological Assays}

The antibacterial activity of compounds was evaluated by the conventional broth dilution assay [24,25]. The MICs were tested in 96-well microtiter plates, and the concentrations of the compounds were serial double dilution which were certain in each well. The MICs were determined as the lowest concentrations at which no growth was observed. The MBCs were determined by transferring approximately $0.0015 \mathrm{~mL}$ from each well of the microtiter plate with the MIC 2000 inoculator to a petri dish ( 15 by $150 \mathrm{~mm}$ ) containing solid LB culture. The plates were incubated at $35^{\circ} \mathrm{C}$ for $48 \mathrm{~h}$. The MBCs were read as the lowest concentrations of compounds that prevented growth 
of more than one colony on subculture. The test range of compounds 1-8 was 0.039-20.0 $\mu \mathrm{M}$ and the test range of positive control was 0.010-10.0 $\mu \mathrm{M}$. Five bacterial strains S. albus (ATCC 23361), S. aureus (ATCC 27154), E. coli (ATCC 25922), V. parahaemolyticus (ATCC 17802), and V. anguillarum (ATCC 19109) were used, and ciprofloxacin was used as a positive control.

The lethality to the brine shrimp A. salina was tested according to the method in literature [26]. The brine shrimp A. salina eggs (Tianjin Red Sun Aquaculture Co., LTD., Tianjin, China) were incubated in nature seawater from Yellow Sea in Qingdao, China and oxygenated with an aquarium pump at $25{ }^{\circ} \mathrm{C}$ for $48 \mathrm{~h}$. The nauplii of brine shrimp were separated from the eggs in small beakers containing sea water. The test compounds were dissolved in DMSO and the serial diluted concentration ranges of the compounds 1-8 were $0.625-100 \mu \mathrm{g} / \mathrm{mL}$. In 24-well microplates, 15-20 brine shrimp in each well were incubated with the test compounds for $24 \mathrm{~h}$. The lethality rates were observed and the $\mathrm{LC}_{50}$ values were calculated by Probit analysis.

\section{Conclusions}

In summary, three new diphenyl ether derivatives-phomaethers A-C (1-3) together with five known compounds-2,3'-dihydroxy-4-methoxy-5',6-dimethyl diphenyl ether (4), diaportinol (5), desmethyldiaportinol (6), citreoisocoumarinol (7), and citreoisocoumarin (8)-were isolated from a gorgonian-derived Phoma sp. fungus collected from the South China Sea. It was the first example of diphenyl glycoside derivatives obtained from coral-derived fungi. Diphenyl ether derivatives 1, 3, and 4 showed strong antibacterial activity, suggesting that they might have potential to be developed as antibacterial agents.

Supplementary Materials: The NMR and MS spectra of 1, 2, and 3 are available on line at www.mdpi.com/16603397/15/6/146/s1 in Figures S1-S21.

Acknowledgments: This work was supported by the National Natural Science Foundation of China (No. U1406402), The Scientific and Technological Innovation Project Financially Supported by Qingdao National Laboratory for Marine Science and Technology (No. 2015ASKJ02), The Ocean Public Welfare Program, State Oceanic Administration of China (201405038), and the Taishan Scholars Program, China.

Author Contributions: T. Shi performed data analysis and manuscript preparation; J. Qi performed fermentation, extraction, and isolation; C.-L. Shao collected the coral specimen; D.-L. Zhao and X.-M. Hou modified the manuscript. C.-Y. Wang was the project leader, organizing and guiding the experiments and manuscript writing.

Conflicts of Interest: The authors declare no conflict of interest.

\section{References}

1. Zhou, S.L.; Wang, M.; Feng, Q.; Lin, Y.Y.; Zhao, H.E. A study on biological activity of marine fungi from different habitats in coastal regions. SpringerPlus 2016, 5, 1966-1973. [CrossRef] [PubMed]

2. Kobayashi, J.I. Search for new bioactive marine natural products and application to drug development. Chem. Pharm. Bull. 2016, 64, 1079-1083. [CrossRef] [PubMed]

3. Jha, R.K.; Xu, Z.R. Biomedical compounds from marine organisms. Mar. Drugs 2004, 2, 123-146. [CrossRef]

4. Hou, X.M.; Xu, R.F.; Gu, Y.C.; Wang, C.Y.; Shao, C.L. Biological and chemical diversity of coral-derived microorganisms. Curr. Med. Chem. 2015, 22, 3707-3762. [CrossRef] [PubMed]

5. Mohamed, I.E.; Gross, H.; Pontius, A.; Kehraus, S.; Krick, A.; Kelter, G.; Maier, A.; Fiebig, H.H.; König, G.M. Epoxyphomalin A and B, prenylated polyketides with potent cytotoxicity from the marine-derived fungus Phoma sp. Org. Lett. 2009, 11, 5014-5017. [CrossRef] [PubMed]

6. Kong, F.D.; Wang, Y.; Liu, P.P.; Dong, T.H.; Zhu, W.M. Thiodiketopiperazines from the marine-derived fungus Phoma sp. OUCMDZ-1847. J. Nat. Prod. 2014, 77, 132-137. [CrossRef] [PubMed]

7. Loesgen, S.; Bruhn, T.; Meindl, K.; Dix, I.; Schulz, B.; Zeeck, A.; Bringmann, G. (+)-Flavipucine, the missing member of the pyridione epoxide family of fungal antibiotics. Eur. J. Org. Chem. 2011, 2011, 5156-5162. [CrossRef]

8. Shim, S.H.; Baltrusaitis, J.; Gloer, J.B.; Wicklow, D.T. Phomalevones A-C: Dimeric and pseudodimeric polyketides from a fungicolous Hawaiian isolate of Phoma sp. (Cucurbitariaceae). J. Nat. Prod. 2011, 74, 395-401. [CrossRef] [PubMed] 
9. Chen, M.; Shao, C.L.; Meng, H.; She, Z.G.; Wang, C.Y. Anti-respiratory syncytial virus prenylated dihydroquinolone derivatives from the gorgonian-derived fungus Aspergillus sp. XS-20090B15. J. Nat. Prod. 2014, 77, 2720-2724. [CrossRef] [PubMed]

10. Zhao, D.L.; Shao, C.L.; Zhang, Q.; Wang, K.L.; Guan, F.F.; Shi, T.; Wang, C.Y. Azaphilone and diphenyl ether derivatives from a gorgonian-derived strain of the fungus Penicillium pinophilum. J. Nat. Prod. 2015, 78, 2310-2314. [CrossRef] [PubMed]

11. Cao, F.; Yang, Q.; Shao, C.L.; Kong, C.J.; Zheng, J.J.; Liu, Y.F.; Wang, C.Y. Bioactive 7-oxabicyclic [6.3.0] lactam and 12-membered macrolides from a gorgonian-derived Cladosporium sp. fungus. Mar. Drugs 2015, 13, 4171-4178. [CrossRef] [PubMed]

12. Shao, C.L.; Xu, R.F.; Wei, M.Y.; She, Z.G.; Wang, C.Y. Structure and absolute configuration of fumiquinazoline L, an alkaloid from a gorgonian-derived Scopulariopsis sp. fungus. J. Nat. Prod. 2013, 76, 779-782. [CrossRef] [PubMed]

13. Sun, X.P.; Cao, F.; Shao, C.L.; Chen, M.; Liu, H.J.; Zheng, C.J.; Wang, C.Y. Subergorgiaols A-L, 9, 10-secosteroids from the South China Sea gorgonian Subergorgia rubra. Steroids 2015, 94, 7-14. [CrossRef] [PubMed]

14. Weber, H.A.; Gloer, J.B. Interference competition among natural fungal competitors: An antifungal metabolite from the coprophilous fungus Preussia fleischhakii. J. Nat. Prod. 1988, 51, 879-883. [CrossRef]

15. Larsen, T.O.; Breinholt, J. Dichlorodiaportin, diaportinol, and diaportinic acid: Three novel isocoumarins from Penicillium nalgiovense. J. Nat. Prod. 1999, 62, 1182-1184. [CrossRef] [PubMed]

16. Aly, A.H.; Edrada-Ebel, R.; Wray, V.; Müller, W.E.G.; Kozytska, S.; Hentschel, U.; Proksch, P.; Ebel, R. Bioactive metabolites from the endophytic fungus Ampelomyces sp. isolated from the medicinal plant Urospermum picroides. Phytochemistry 2008, 69, 1716-1725. [CrossRef] [PubMed]

17. Lai, S.; Shizuri, Y.; Yamamura, S.; Kawai, K.; Furukawa, H. Three new phenolic metalolites from Penicillium species. Heterocycles 1991, 32, 297-305.

18. Zhang, H.; Yang, F.; Qi, J.; Song, X.C.; Hu, Z.F.; Zhu, D.N.; Yu, B.Y. Homoisoflavonoids from the fibrous roots of Polygonatum odoratum with glucose uptake-stimulatory activity in 3T3-L1 adipocytes. J. Nat. Prod. 2010, 73, 548-552. [CrossRef] [PubMed]

19. Kornsakulkarn, J.; Thongpanchang, C.; Lapanun, S.; Srichomthong, K. Isocoumarin glucosides from the scale insect fungus Torrubiella tenuis BCC 12732. J. Nat. Prod. 2009, 72, 1341-1343. [CrossRef] [PubMed]

20. Du, L.; Zhu, T.J.; Liu, H.B.; Fang, Y.C.; Zhu, W.M.; Gu, Q.Q. Cytotoxic polyketides from a marine-derived fungus Aspergillus glaucus. J. Nat. Prod. 2008, 71, 1837-1842. [CrossRef] [PubMed]

21. Yun, B.S.; Cho, Y.; Lee, I.K.; Cho, S.M.; Lee, T.H.; Yoo, I.D. Sterins A and B, new antioxidative compounds from Stereum hirsutum. J. Antibiot. 2002, 55, 208-210. [CrossRef] [PubMed]

22. Serianni, A.S.; Barker, R. [13C]-Enriched tetroses and tetrofuranosides: An evaluation of the relationship between NMR parameters and furanosyl ring conformation. J. Org. Chem. 1984, 49, 3292-3300. [CrossRef]

23. Kong, X.L.; Ma, X.H.; Xie, Y.Y.; Cai, S.X.; Zhu, T.J.; Gu, Q.Q.; Li, D.H. Aromatic polyketides from a sponge-derived fungus Metarhizium anisopliae mxh-99 and their antitubercular activities. Arch. Pharm. Res. 2013, 36, 739-744. [CrossRef] [PubMed]

24. Appendino, G.; Gibbons, S.; Giana, A.; Pagani, A.; Grassi, G.; Stavri, M.; Smith, E.; Rahman, M.M. Antibacterial cannabinoids from Cannabis sativa: A structure-activity study. J. Nat. Prod. 2008, 71, 1427-1430. [CrossRef] [PubMed]

25. Kirven, L.A.; Thornsberry, C. Minimum bactericidal concentration of sulfamethoxazole-trimethoprim for Haemophilus influenzae: Correlation with prophylaxis. Antimicrob. Agents Chemother. 1978, 14, 731-736. [CrossRef] [PubMed]

26. Solis, P.N.; Wright, C.W.; Anderson, M.M.; Gupta, M.P.; Phillipson, J.D. A microwell cytotoxicity assay using Artemia salina (brine shrimp). Planta Med. 1993, 59, 250-252. [CrossRef] [PubMed]

(C) 2017 by the authors. Licensee MDPI, Basel, Switzerland. This article is an open access article distributed under the terms and conditions of the Creative Commons Attribution (CC BY) license (http:/ / creativecommons.org/licenses/by/4.0/). 